\title{
New Approaches to Cinematic Space
}

New Approaches to Cinematic Space aims to discuss the process of creation of cinematic spaces through moving images and the subsequent interpretation of their purpose and meaning. Throughout 17 chapters, this edited collection will attempt to identify and interpret the formal strategies used by different filmmakers to depict real or imaginary places and turn them into abstract, conceptual spaces. The contributors to this volume will specifically focus on a series of systems of representation that go beyond the mere visual reproduction of a given location to construct a network of meanings that ultimately shapes our spatial worldview.

Filipa Rosário (PhD Artistic Studies - Cinema Studies, University of Lisbon) is a researcher in the Centre for Comparative Studies (UL), where she coordinates the project 'Cinema and the World - Studies on Space and Cinema'. She is the author of O Trabalho do Actor no Cinema de John Cassavetes (2017).

Iván Villarmea Álvarez (PhD History of Art, Universidad de Zaragoza) works as a researcher at the Universidade de Santiago de Compostela. He has published the book Documenting Cityscapes. Urban Change in Contemporary Non-Fiction Film (2015) and co-edited the volume Jugar con la Memoria. El Cine Portugués en el Siglo XXI (2014). 


\section{Routledge Advances in Film Studies}

\section{The Cinematic Eighteenth Century}

History, Culture, and Adaptation

Edited by Srividhya Swaminathan and Steven W. Thomas

55 The Contemporary Femme Fatale

Gender, Genre and American Cinema

Katherine Farrimond

56 Film Comedy and the American Dream Zach Sands

57 Ecocinema and the City

Robin L. Murray and Joseph K. Heumann

58 Collective Trauma and the Psychology of Secrets in Transnational Film

Deborah Lynn Porter

59 Melodrama, Self and Nation in Post-War British Popular Film Johanna Laitila

60 Emotion in Animated Films

Edited by Meike Uhrig

61 Post-Production and the Invisible Revolution of Filmmaking From the Silent Era to Synchronized Sound

George Larkin

62 New Approaches to Cinematic Space

Edited by Filipa Rosário and Iván Villarmea Álvarez

For more information about this series, please visit: https://www.routledge.com 


\title{
New Approaches to Cinematic Space
}

\author{
Edited by
}

Filipa Rosário and

Iván Villarmea Álvarez 


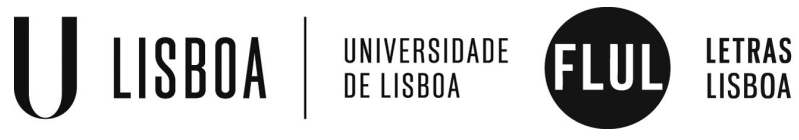
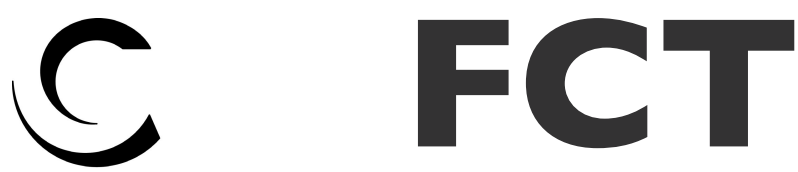

Centro de Estudos

Fundação

Comparatistas para a Ciência e a Tecnologia

This work is funded by Portuguese national funds through FCT - Fundação para a Ciência e a Tecnologia, I.P., in the scope of the project UID/ELT/ $0509 / 2013$. 
First published 2018

by Routledge

52 Vanderbilt Avenue, New York, NY 10017

and by Routledge

2 Park Square, Milton Park, Abingdon, Oxon OX14 4RN

Routledge is an imprint of the Taylor \& Francis Group, an informa business

(C) 2019 Taylor \& Francis

The right of Filipa Rosário and Iván Villarmea Álvarez to be identified as the author of the editorial material, and of the authors for their individual chapters, has been asserted in accordance with sections 77 and 78 of the Copyright, Designs and Patents Act 1988.

All rights reserved. No part of this book may be reprinted or reproduced or utilised in any form or by any electronic, mechanical, or other means, now known or hereafter invented, including photocopying and recording, or in any information storage or retrieval system, without permission in writing from the publishers.

Trademark notice: Product or corporate names may be trademarks or registered trademarks, and are used only for identification and explanation without intent to infringe.

Library of Congress Cataloging-in-Publication Data

[CIP data]

ISBN: 978-1-138-60444-5 (hbk)

ISBN: 978-0-429-46849-0 (ebk)

Typeset in Sabon

by codeMantra 


\section{Contents}

List of Figures and Maps xi

Acknowledgements xiii

Introduction: Screen is the Place 1

FILIPA ROSÁRIO AND IVÁN VILLARMEA ÁLVAREZ

PART 1

Urban Spaces

1.1 Memoryscapes: Mapping Urban Space through Amateur Film Archives

PAOLO SIMONI

1.2 Social Space, Architecture and the Crisis: Neo-noir Aesthetics in Contemporary Greek Cinema

ANNA POUPOU

\section{PART 2}

Architectural Spaces

2.1 The Architectural Space Generated by Staircases in Alfred Hitchcock's Films

MARÍA NOVELA DE ARAGÓN

2.2 Stranger than Paradise - Realities of Cinema,

Architectural Imageries, Circa 1956 
viii Contents

PART 3

Genre Spaces

3.1 Empire of Catalandia: Science Fiction as the Cinematic Space of the Anthropocene

MAURIZIA NATALI

3.2 The Urban and the Domestic: Spaces of American Film Noir SÉRGIO DIAS BRANCO

3.3 Film Noir and the Folding of America: A Reading of Out of the Past (1947) and Impact (1949)

JEFFREY CHILDS

PART 4

Spectral Spaces

4.1 Blinking Spaces in Contemporary Psychogeographical Documentaries

IVÁN VILLARMEA ÁLVAREZ

4.2 On the 'Ghosts' of Piramida: Ruins, Memory and Music JOSÉ DUARTE

4.3 Remembering a Fabricated City: Visiting Terezín in Daniel Blaufuks's As if...

PART 5

Heterotopic Spaces

5.1 On Location: Kiarostami's Landscapes and Cinematic Value MARIA IRENE APARÍCIO

5.2 Mapping Heterotopias in Colombian Documentary Film MARIA LUNA

5.3 Cinematographic Missions to the Portuguese Territory (1917-1918) 
PART 6

Phenomenology of Space

6.1 The Viewer's Embodiment into Cinematic Space:

Notes on a 'Space-Image' Cinema

ANTOINE GAUDIN

6.2 Towards the Spatial Affectivities of Colour: The Blue

Bedroom in Yasujirō Ozu's An Autumn Afternoon

SANDER HÖLSGENS

6.3 Cinema, Allospaces and the Unfilmable

BRUNO SURACE

6.4 Framing Doors, Opening Up Spaces: Cristi Puiu and His

Cruel Phenomenology of Space

ZSOLT GYENGE

List of Contributors

Index 


\title{
2.2 Stranger than Paradise - Realities of Cinema, Architectural Imageries, Circa 1956
}

\author{
Francisco Ferreira
}

In the aftermath of the Second World War, the proposals and thoughts on architecture would once again move towards a hopeful - although careful - insight over the modern imagery. Still sustained by ideals of systematisation, standardisation, rationalisation and progress, such proposals and thoughts would, nevertheless, also correspond to a critique of modernist orthodoxy, to the exaltation of the subjective, to an idea of conflict and, consequently, to an architectural configuration of such feelings. The rise of a subject who not only recognises but also allocates to the conception of space a communication meaning - rather than a formal one - would become a major influence on the way designers interpret the built environment, thus leading to the fragmentation of a macro perception and to a repositioning of the principles and purposes of architectural intervention. This, in turn, would lead to a reduction of scale, which would naturally emphasise the importance of individual space and of one's habitat, but such a reduction would also bare the idea of a globalised way of life, thoroughly connected, extensible and infrastructured.

Modernism always progressed in the exact proportion to which it configured itself as a movement of crisis. In this sense, we may assume that to be modern is always to promote a fractured path, while holding hope that the fracture will eventually become a home and that it may be circumscribed, not only theoretically, but also historiographically i.e. temporally. After the 'first machine age', modern architecture found itself at crossroads: from the debris of two world wars, the modernist horizon would reappear as composed by disparate fragments, which would simultaneously encompass symbolical views of the vernacular, emotional bets on the present and hedonistic wishes for the future. This means that what distances the first modern age from the one that succeeds the Second World War is that within the latter, modernism acknowledges and surrenders itself to an external temporal condition, no longer imposing itself, in a positivistic way, as time itself. Such an acknowledgement would bring to the fore the realisation that reality is built upon discontinuities, thus transforming the modernist imagery into an interspersed ideology, now closer to the circumstance of the 
intimate, individual desire. This would lead to a repositioning of the modern towards the making of reality, from an inward, autonomous and abstract-based condition, to one of openness and interaction with the idea of circumstance, sustained in an operative critique of everyday life.

Throughout the 1950s and 1960s, the artistic and architectural avant-gardes would thus engage on a reassessment of their creative processes. They did so by incorporating an idea of daily life charged with epistemological relevance and nourished by fewer scholarly cultural references - more popular, above all more 'pop' - and an ambiguous political context, swaying between a post-war fading optimism, the growing scepticism resulting from the nuclear escalade and a fascination towards the imageries created by the growing research and news on space travel. This reassessment would inevitably address the act of inhabiting - understood now as an experience instead of a destiny through formulations of its configurations and its territorial and cultural positioning, in a process of rediscovery of its new ethos. The future was being intensely imagined from a present tainted by the idea of permanent change and mobility together with a sense of wonder brought up by the promises of new technologies, mainly as a means for the globalisation of the human condition.

Architectural principles would inevitably feel the effects of these assumptions, particularly those that traditionally characterised domestic space, which, from here on, would come to incorporate in its formulation traditionally, a formulation of intimacy - a deduction of the act of inhabiting as both a creative and critical process. Such a formulation would thus engage in a generic inquiry - more often into a provocation rejecting the condition of being a mere response or specific proposition, as happened within the first age of modernism. This meant that form, no longer unscathed in following function, would become in itself a procedural figure, transforming the process of its conception and design into a system of thought and, above all, into an instrument for an exchange between the architectural act, technology and the characterisation of territory. This is why the domestic building would grow closer to the body - as a multifunctional complex structure - not just an object of mediation between man and environment anymore, but rather an artificial extension for the manipulation of said environment.

This environmental and global awareness would overcome the character of contemporary domestic space with a reinforcement of its introspection, leading its architectural pathos into a paradox. We may find this paradox perfectly encapsulated in 1956, through proposals such as The House of the Future, created for The Daily Mail's Ideal Home Exhibition by architects Alison and Peter Smithson, as well as Richard Hamilton's 'This is Tomorrow' exhibition collage entitled, Just What Is It That Makes Today's Homes So Different, So Appealing? or Fred Wilcox's film Forbidden Planet. In all these cultural productions, there 
is a kind of predicament for a 'civilisational' reassertion, in which the architecture of the home and its narratives seem to play an important and relevant part. In fact, in these proposals, the conceptions of the 'house' seem to concentrate its main efforts towards the transformation of intimate space into a sort of enclosed total environment, an existential enclave of Edenic qualities, to be located anywhere or nowhere.

\section{Just What Is It That Makes Today's Homes So Different, So Appealing?}

In Richard Hamilton's collage title for Group Two's poster at the 'This is Tomorrow' exhibition, the question 'Just What Is It That Makes Today's Homes So Different So Appealing?' may be understood, if read rhetorically, as both a statement and a proposal. It can be read as a statement in that it immediately declares that, in fact, 'today's homes' are already different and appealing. It can be read as a proposal because the image appears to be presenting a kind of atmosphere, which is understood to effectively make a home 'different' and 'appealing'. So, there is a twofold significance to Hamilton's collage: it seems to recognise 'today's homes' as already different and appealing (in which it becomes a kind of portrait), while at the same time, it also synthesises and reveals what may produce such an effect (in which it projects a new image of what a 'home' could, effectively, become).

Although produced to be included in the exhibition's catalogue, it was not part of the exhibit (Robbins, 1990, p. 69) and was subsequently used as a poster. Its creation, which only took a single morning, followed a guide list of 'things' that Hamilton wanted to represent: "Man, Woman, Humanity, History, Food, Newspaper, Cinema, TV, Telephone, Comics (picture information), Words (textual information), Tape recording (aural information), Cars, Domestic Appliances, Space” (Stonard, 2007, p. 613). ${ }^{1}$ It is worth noting that Hamilton explained a specific purpose for the comics, words and tape recording, respectively, highlighting the issues of pictorial, textual and aural perception. In this sense, such items/ issues are included in the image conception, so as to produce an emphasis on the sensorial quality of the space depicted. And although constructed over a perspectival representation of a common living room - an advertisement image for the Armstrong Royal Floors taken from a June 1955 issue of the Ladies' Home Journal was the basis for Just what is it...? (Stonard, 2007, p. 615) - Hamilton's collage may better be read as a flat image in which an ambiguous figure and ground play establishes a feeling of simultaneity, rather than sequence.

From the point of view of optical projection, Just what is it...? holds several inaccuracies, leading us to understand in it not an intention to objectively represent space, but a will to subjectively conceive it. This means that the scene depicted in Just what is it...? is not primarily 
defined through geometry, but through the interplay of two major situations, which Hamilton patched alongside or over each other. Although we are led to understand the collage as a domestic scene with a twist of pop indulgence thrown at it, a particularly striking result is the juxtaposition of such a scene together with a glimpse of an aerial view of planet Earth that occupies the upper space of the image where before a ceiling composed of painted wooden beams existed. Although occupying the major part of the image, the staging of the domestic scene is clearly on par with the density and subsequent presence of the planet. The portion, taken from A Hundred Mile High Portrait of Earth - from a double-page feature published in Life magazine on 5 September 1955 (Stonard, 2007, pp. 615-616) - is actually turned upside down from its original orientation, thus assuming a relative position towards the image of the room. In this sense, it does not work as an image patched onto the ceiling surface, but as an independent figure, one that actually places the domestic scene within a cosmic scale. The room thus holds a dimensional flexibility, which, together with the presence of the hovering planet above it, establishes an extensible but inclusive spatial bias. The narrow black - or negative - space which mediates the image of the planet with that of the interior of the room is but a portion of a continuous background that, while holding both objects, is consequently determined by their presence and contour. Both room and planet are figures that share an equivalent importance and presence within the composition and are as complementary to each other as they are improbable in the way as such a complementarity is depicted. Just what is it...? is an image representing the overlapping status of the universal and the particular through a simultaneous interplay of the senses: the extension and depth of cosmic space resonate inside the room scene and articulate with its domestic atmosphere.

Just what is it...? may then be thought of as a spatial phenomenal 'construction', one that dislocates the geographical context of the original image, in that the domestic interior becomes the interior of a space capsule either in orbit or departing from Earth. In doing so, it is simultaneously evoking the idea of a new civilisational beginning, represented through the relaxed and proud pose of the two naked figures who, as original Man and Woman - Richard Hamilton referred to these characters as Adam and Eve (Stonard, 2007, p. 618) - inhabit this new environment as if it contained the whole of humanity's cultural and historical futures.

\section{House of the Future}

Commissioned to be a part of the ' 60 Years On' section of the Daily Mail Jubilee Display, which was an integral part of the Daily Mail Ideal Home Exhibition, the House of the Future, designed by architects 
Alison and Peter Smithson, projected a mere 25 years into the future, for, as was stated by its authors, "this period is likely to produce as many revolutionary changes as the past one hundred years" (Alison \& Peter Smithson quoted in Colomina, 2007, pp. 215-216). Similar to the artefacts on the accompanying displays focusing on the space programme, the House of the Future presented itself, first and foremost, as an image to be consumed: not being a real prototype for the modern house but a fictional realisation of an imagery deeply influenced by both the space age cultural context and the anguished atmosphere evolving around the nuclear threat, this house - displayed as a human scale model - would enunciate itself as a territory. Not only did it establish a limit, preventing any immediate or literal connection with its surroundings, it actually built itself as an autonomous compact and enclosed object. It was, in this sense, a domestic space conceived as a last resort for survival, overlapping an act of appropriation with one of defence.

As a way to metaphorically charge such a strange architectural apparatus, the Smithsons gave specific instructions to the exhibition organisers to include on the inside of the house, "a book, to lie open at a space man plate, on one of the chairs, and a snap of someone on MARS to be placed in a silver frame in a compartment on the dressing room" (Colomina, 2007, p. 214). Adding to these references, the Smithsons also requested an underwater film, like The Silent World (Le monde $d u$ silence, Jacques-Yves Cousteau \& Louis Malle, 1956), to "be shown on the back projection TV, to run longer than it would take a person to complete a circuit of the house" (Alison \& Peter Smithson quoted in Colomina, 2007, p. 228). In this way, the H.O.F. also "becomes a submarine, moving underwater with the TV built into the wall as a porthole, and the gasket joints running across every surface preventing any leaks" (Colomina, 2007, p. 228). Although having been described by the Smithsons as being "designed to build up into a dense mass" (Alison \& Peter Smithson, 1994, p. 115), the H.O.F., Colomina states, "was likewise a science-fiction vehicle. Even what was playing on TV reinforced the sense of a moving space cut out from the terrestrial world" (2007, p. 214).

In the issue of 12 March 1956, the Daily Mail newspaper presented a description of the House of the Future, as told by two special visitors, the siblings Barbara and Hugh Clift, who were just nine and seven years old, respectively. Beginning the article - written by Patricia Keighran, to whom presumably the siblings had described their views on the house - a title read: "The Clift children see a house of magic which will welcome them as grown-ups" (1956, p. 3). There are two images accompanying the article: the first shows a mid-close documentary portrait of the Clift children, holding hands, standing on top of the elevator living room table and looking up to the camera as they themselves explain 
[w]ell we went into the living-room of the House of the Future and it was weird, and we felt a bit lost, especially when someone said we were standing on the table. The table turned out to be great fun. It comes out of the floor when you need it.

(Keighran, 1956, p. 3)

The second image is much more elaborate: while the upper point of view is maintained, a wider view of the living room is depicted - one that shows a glimpse of an interior garden - with a couple of make believe inhabitants - apparently called Anne and Peter. Juxtaposed to the picture, a series of comic-like labels identifies every item in view, including the fact that the characters are wearing all nylon clothes. The labels mainly describe the gadgetry quality of the objects: among others, there is a "trolley with warmed compartment and infrared griller", "air-conditioning controls and a loud-speaking telephone which records message" or a "sunken self-rising bath" (Keighran, 1956, p. 3). Similar to Hamilton's home of today, the House of the Future was depicted as a contained environment full of objects. Accompanying the Daily Mail article on the Clifts' visit, an exclamation that we may attribute to either the children or the inhabitants themselves mediates the two pictures and states the fantastic allure of the space: "Look! We're in Wonderland" (Keighran, 1956, p. 3).

The paradoxical glamour emanating from the staged interior of this house thus becomes a re-enactment of a beginning, a new beginning. For, as if it were a theatrical production, actors were hired, clothes designed and scenes choreographed, so that those visiting the house - a visit limited to a peripheral elevated path - could have a glimpse of the daily atmosphere and experience of such an environment, an atmosphere that was further enhanced with the presence of the enigmatic interior garden, created by the architects as a direct evocation of the biblical Eden. Peter Smithson addresses a 1,400 German painting entitled The Garden of Paradise as one of the "conscious cribs" of the House of the Future (Colomina, 2000, p. 24). This conscious use of such imagery, as stated by Smithson, thus puts upon this house - pragmatically designed to be a technological standardised device - a specific significance and purpose, as it becomes a means of reconstructing a very particular mythological moment, transformed into a spatial experience, which aims at preceding any sort of technological knowledge or existential anxiety.

\section{Forbidden Planet}

Forbidden Planet, a 1956 film directed by Fred Wilcox and produced by MGM, delved into the idea of space travel and the discovery of new civilisations and technological capabilities. It did so in a way in which technology was to be seen, in its most fundamental reason of being, as 
a human, natural factor. Presented as a big production by the studios, Forbidden Planet adapted William Shakespeare's The Tempest (1611) and aimed at overcoming the success of previous science fiction films. The film starts with the arrival of a search party from Earth to planet Altair IV, attempting to find out what happened to a previous scientific exploration group who had mysteriously disappeared. In a scan previous to their descent upon the estranged planet, Lieutenant Jerry Farman declares: "I may be missing some kind of individual structure, but there are no cities, ports, roads, bridges, damns... there is no sign of civilisation!" In fact, Lieutenant Jerry Farman was missing the presence of a house: the home of Morbius, a scientist from the previous group, and Altaira, his native-born daughter.

Shaped like a flying saucer - which, interestingly, is also the shape of the Earth's spaceship, a choice of design that we believe acknowledges the alien condition of the human species in the planet - the house of Dr. Morbius and Altaira is the only built structure on the planet. The 'residence', ${ }^{2}$ although located in a desolated, wild and sterile landscape, is paradoxically surrounded by an unexpected and luxurious garden. Unlike the House of the Future, it is the garden that encloses the domestic territory, thus isolating it from the menacing exterior scenery. Nevertheless, and almost as wishing to go against this close and rather kind landscape, the interior of the house is carved into a rock, producing a rather austere and cavernous feeling.

During the first part of the film, while the premises of the plot are unfolding, we lead to observe the characters' interactions with the house: space is continuous between its interior and the garden, its foundational and original character reinforced with the presence of wild animals (such as dears, a tiger and a monkey), hanging out peacefully with each other, but also with the house inhabitants, especially with Dr. Morbius' daughter Altaira, whose appalling innocence subliminally emphasises the will to create a pure and domesticated territory. Akin to the Smithsons' House of the Future, but also to Hamilton's Today House, Altair IV's residence is not only 'different' or 'appealing' because of its form and technological infrastructure, but mainly for its qualities as a mechanism for survival, defined as an idealised total environment. As with the House of the Future, Morbius and Altaira's house is conceived as a safe place in an imaginary world, a docile place encased within a dreadful atmosphere originating in the demise of the remaining members of the scientific campaign at the hands of a strange "planetary force, a terrible, incomprehensible and dark force", as put by Dr. Morbius himself. To prevent further attacks from such a force, which we are allowed to observe as the film progresses in its destructive manifestations towards any sort of matter, Dr. Morbius demonstrates a defensive system to his visitors, which, from a single movement of the hand over a photovoltaic 
cell, allows the house to become completely and quickly enclosed, thus literally becoming an armoured fortress.

Stationed nearby, the Earth's ship commanded by skipper J. J. Adams adopts a similar defensive attitude: a perimeter is set around it, along which an electrical fence reinforces the ship's sealed surface. Here, as in the House of the Future, "the latest technologies are used to establish a sense of security" (Colomina, 2007, p. 228). In fact, ending the first encounter between the Earth's spaceship crew members and Dr. Morbius, the latter insists on warning commander Adams about the perils of staying on the planet. To reinforce his point, he reveals the place where the dead crew members of his own party are buried: a graveyard, well within the house's visual range, is sighted by both, establishing an uncanny transition between the garden and the wild landscape surrounding it. The Eden-like setting, then, while representing a place of quietude and purity, still exists within an area of impending disaster and holds the memory of death.

Throughout the film, we end up learning that Altair IV has a nuclear core with an almost unlimited power that feeds a fully functional technological centre, once pertaining to an incredibly advanced civilisation, the Krell. Such spaces are, in turn, connected to the house by bunkered underground corridors. Such a power, we will also learn, is the same that, upon contact with the mind, unleashes its darkest fears as ghostly electrical monsters that attack anything it subconsciously feels as representing a menace. Thus, the domestic armoured house of Altair IV half-spaceship, half-cave - becomes both a territory of defence and the womb of a subliminal anxiety on gaining control over the unknown.

The film ends with Morbius unable to resist the uncontrolled fury of his own mind, which turned out to be the unconscious origin of the 'planetary force', a consequence of his previous interactions with the Krell's technology - one "capable of harnessing the collective power of thought, sending it anywhere in the universe they chose in any shape or form they wished" (Hollings, 2008, p. 177). Marvelling at such an achievement, Dr. Ostrow, one of the Earth's visiting crew members to the planet, wonders: "a civilisation without instrumentality!"

As a cinematic device, the house of Dr. Morbius and Altaira is treated rather bluntly, just on par with the rest of the film's décor. Entirely shot on set, the house - together with its bunkered huge underground - and Earth's spaceship are the only structures to stand out from the painted backgrounds. Their main purpose is, nevertheless, not one of constructing believable settings in which to contextualise the narrative, but to present themselves as a substantial part of such narrative. In this sense, the film does not substantially try to be credible with the places it presents in the sense that we, as spectators, should actually feel as watching a story set on another planet, but unfolds as if we were watching the unravelling 


\section{Francisco Ferreira}

of a play, in which the sets become characters in their own right, as a discourse transformed into topoi. Apart from some other minor scenes, the film sets its main action between the place where Earth's spaceship landed - its presence always central to each scene - and Dr. Morbius and Altaira's house, where the story actually comes into being: it is through the interaction of the characters themselves, and with this strange domestic environment, that the pace of the film gains momentum.

The ulterior spaces underneath the house lead both characters and viewers to discover the underground world of the Krell, which, contrary to the flattened feel of the rest of the film, becomes a space with depth and scale. The camera hovers over it in the sequence of its revelation as a whole, making quite difficult to identify the presence of the characters that explore it. In doing so, the film amplifies the fundamentals of representation and the architectural ability to create powerful and operative images. Such images, which are more than mere bi-dimensional illustrations, appear to us as simulacra, as something that do not exist outside the realm of their own representation, thus configuring themselves as an actual experience. Similar to the enactment that was held at the House of the Future - one that was not only a performance for the exhibition, but a fundamental part of the fictional narrative contained in the concept and imagery of the house, and thus of architecture - the set design structures in Forbidden Planet - within the scope and 'reality' of their being as film, thus as cinema - become a means to establish space (place) and time (sequence) not as frame, but as subjects of an ever going path onto the discovery and representation of the unknown.

\section{Stranger than Paradise}

In Modern Architecture's first machine age conceptions, interior space established a direct connection with its surroundings. In its more radical realisations, the curtain wall enclosure aimed at positioning 'Man', always and continuously, within a broader physical and visual context. In Toward an Architecture, Le Corbusier would state that "the outside is always an inside" (2007, p. 224), thus establishing a structural liaison between the exterior and the interior that framed a sort of inversion between more canonical definitions of place and architecture. Writing from a point of view that enhances the power of vision over any other of Man's senses, Le Corbusier's statement - prior to any other proposition implies the exterior as matter for the interior, thus reinforcing the character of the site as an operative instrument for the organisation of any architectural intervention.

The examples discussed earlier, conceived within a context of revision of the early modern architectural assumptions and in a moment of cultural and social reactions to the war's devastation, together with 
a growing insecurity towards the nuclear menace, seem to cut away from some of the most established modernist considerations, transforming the space of the interior into an absolute environment. The built-in TV showing underwater landscapes in the Smithson's House of the Future is, in this sense, the equivalent to both the upper view and the presence of planet Earth in Hamilton's Today House collage, and to the surrounding desert of Dr. Morbius and Altaira's residence in Forbidden Planet. Each one of these images, to which each one of the architectural structures opposes, determines a connection based on a confrontation with each one of the inner spaces. Consequently, from the point of view that conceives each one of these places, to be inside means to inhabit a subjective desire for the exterior that, at the same time, is feared. In this sense, each one of these houses may be interpreted not only as a projection in time, but above all as a sort of spatial interjection. They are exquisite domestic environments that "Look! We're in Wonderland" - encapsulate paradoxical and strange dimensions, scales and existential routines: they act as small breaches in the space-time continuum, abnormal and fragmented architectural and cultural events that, nevertheless, are able to encapsulate the whole of the cosmos.

\section{Notes}

1 According to Stonard, The list is reprinted in R. Hamilton: Collected Works (1953-1982), London, 1982, p. 24. There is no copy of this list in Hamilton's archive.

2 As it is called by Robbie, the Robot, the house's all-in-one butler, maid and appliance, who would make a curious but enthusiastic appearance on the 'This is Tomorrow' exhibition.

\section{Works Cited}

\section{Filmography}

Cousteau, J.-Y., \& Malle, L. (1956). The Silent World (Le monde du silence). Wilcox, F. M. (1956). Forbidden Planet.

\section{Bibliography}

Colomina, B. (2000). Friends of the future: A conversation with Peter Smithson. October, Vol. 94, (pp. 3-30). Cambridge, MA: MIT Press.

Colomina, B. (2007). Domesticity at War. Cambridge, MA: MIT Press.

Hamilton, R. (1982). Collected works (1953-1982). London, UK: Thames and Hudson Ltd.

Hollings, K. (2008). Welcome to Mars: Fantasies of science in the American Century 1947-1959. London, UK: Strange Attractor Press.

Keighran, P. (1956, March 12). The Clift children see a house of magic which will welcome them as grown-ups. Daily Mail, p. 3. 


\section{Francisco Ferreira}

Le Corbusier. (2007). Toward an Architecture. Los Angeles, CA: Getty Research Institute.

Robbins, D. (Ed.). (1990). The Independent Group: Postwar Britain and the Aesthetics of Plenty. Cambridge, MA: MIT Press.

Smithson, A., \& Smithson, P. (1994). Changing the art of inhabitation. London, UK: Artemis.

Stonard, J.-P. (2007). Pop in the age of boom: Richard Hamilton's "Just What Is It That Makes Today's Homes So Different, So Appealing?" The Burlington Magazine, 149(CXLIX), 607-620. 


\section{List of Contributors}

Maria Irene Aparício is an Assistant Professor of Cinema and Artistic Studies in the Faculty of Social Science and Humanities at the New University of Lisbon (Portugal), and a Full Member and Researcher of CineLab - Laboratory of Cinema and Philosophy of Nova's Institute of Philosophy (IFILNOVA). She is the co-author, with Joao Mário Grilo, of the book Cinema \& Filosofia: Compêndio (2014). Her research interests include Cinema and Philosophy, Film Theory, Film Directing, Art's Practices and Research, with main focus on the issues of Art and Science, Film and Memory, Arts, Ethics and Aesthetics and Portuguese Cinema, as well as philosophical, ethical and political problems of contemporary film, art and visual culture. She has published several essays and articles on these subjects.

Sérgio Dias Branco (PhD Film Studies, University of Kent, UK) is an Assistant Professor of Film Studies at the University of Coimbra (Portugal), where he coordinates the film and image studies and LIPA - Laboratory for Investigating and Practicing Art. He also directs the MA in Art Studies. He is an Integrated Researcher at IFILNOVA - Nova Institute of Philosophy - and a member of the film analysis group 'The Magnifying Class' at the University of Oxford. He has been a member of the Direction Board of AIM -Association of Moving Image Researchers since 2014. He co-edits Cinema: Journal of Philosophy and the Moving Image and Conversations: The Journal of Cavellian Studies and is the author of Por Dentro das Imagens: Obras de Cinema, Ideias do Cinema [Within Images: Film Works, Cinema Ideas] (2016).

Sandra Camacho is a PhD student in Comparative Studies at the University of Lisbon, where she is developing a thesis entitled, From the Analogue to Image Retrieval: Concepts of Archival Art in Daniel Blaufuks. She holds an MA in Art and Multimedia from the Faculty of Fine Arts, University of Lisbon (2011) and an MA in Contemporary Art from Sotheby's Institute of Art, University of Manchester (2013). Her main areas of interest are the archive as contemporary art practice, the digital archive, media archaeology, interarts studies and memory studies. 
Jeffrey Childs is an Assistant Professor of English and American Studies at Universidade Aberta (Lisbon, Portugal) and a Researcher at the Center for Comparative Studies and at the Centre for English Studies at the University of Lisbon (Portugal). His current research interest lies in the restructuring of the field of rhetorical studies, insofar as the work carried out in this domain allows for the articulation of older disciplinary areas (literature, history, philosophy) with more recent artistic and multidisciplinary practices. His recent publications include the essays "Poets in Glass Houses: Carlos Drummond de Andrade, Wallace Stevens, Mark Strand” (2016), “Alegoria e Imagem no Filme Broken Blossoms, de D. W. Griffith" (2016) and "Style, Narrative, and Cultural Politics in Bullitt" (2017), among others. Furthermore, he has recently completed a translation of Clepysdra, by the Portuguese symbolist poet Camilo Pessanha.

Paulo Cunha (PhD Contemporary Studies, University of Coimbra, Portugal) is an Assistant Professor of Film Studies at the University of Beira Interior (Covilhã, Portugal), where he coordinates the Master's Degree in Cinema. He is a member of LabCom.IFP research centre (University of Beira Interior) and collaborator on CEIS20 - Centre for Interdisciplinary Studies of the 20th Century (University of Coimbra). Along with Michelle Sales, he co-edited the book Cinema Português: Um Guia Essencial (2013). He is also the editorial coordinator of Aniki: Portuguese Journal of the Moving Image, the coordinator of Jornadas Cinema em Português (University of Beira Interior) and the vice-president of the Portuguese Federation of Film Societies. Moreover, he works as a film programmer at the Curtas Vila do Conde and Porto/Post/Doc international film festivals.

José Duarte teaches North American Cinema and History of Cinema at the School of Arts and Humanities, University of Lisbon (Portugal). $\mathrm{He}$ is a Researcher at ULICES (University Lisbon Centre for English Studies) and has co-edited the books Cinematic Narratives: Transatlantic Perspectives (2017) and The Global Road Movie: Alternative Journeys around the World (2018). His research interests focus on the relationship between the cinema and the city, as well as on independent cinema.

Francisco Ferreira (PhD Architecture, Universidade do Minho, Portugal; and M.Sc. Architecture Metropolis, Universitat Politècnica de Catalunya, Spain) works as a Professor at Escola de Arquitectura da Universidade do Minho (EAUM), where he has been teaching, amongst other subjects, a course on Cities and Cinema since 2010. He is a researcher at Lab2PT, Universidade do Minho, and a co-editor at Jack - Journal on Architecture and Cinema, the second issue of which is about to be published. Moreover, he has written and directed two short films: 
Panorama (2013), which was awarded as the Best National Short Fiction Film at the Arquitecturas Film Festival, Lisbon, and Anywhere (2014).

Antoine Gaudin is an Assistant Professor (Maître de conférences) in Film Studies at University Paris 3 - Sorbonne Nouvelle (IRCAV). He is the author of L'espace cinématographique. Esthétique et dramaturgie (Armand Colin, 2015) and the co-editor of Représentations-limites des corps sexuels dans le cinéma et l'audiovisuel contemporains (Presses de la Sorbonne Nouvelle, 2017). To be published soon: Le vidéoclip musical: approaches théoriques et critiques d'un art pop (Presses du Septentrion, 2019).

Zsolt Gyenge works as an Assistant Professor at the Moholy-Nagy University of Art and Design (Budapest, Hungary), where he teaches courses in film theory, film history and visual communication theory. His field of research includes interpretation theories (phenomenology, hermeneutics), experimental film, video art and Romanian Cinema. He is the author of the book Kép, mozgókép, megértés. Egy fenomenológiai filmelemzés elmélete (Image, Moving Image, Interpretation: A Theory of Phenomenological Film Analysis, 2017). $\mathrm{He}$ is the editor of the scholarly journal on design and visual culture Disegno, and is a member of two international research projects (Space-ing Otherness; Cine-versity). He is currently working on a postdoctoral research project entitled, Expanded Screens: New Spectatorship and Subversion in Contemporary Moving Image Installations. He is also active as a freelance film critic.

Sander Hölsgens (PhD Architectural Design, The Bartlett School of Architecture, University College London) is a Filmmaker and Writer currently working on dust and deserts in Southern California. His films include Reverberations (2016), Blue Bluer (2017) and Clouds of Blue Dust (2018). Moreover, he also works as a visiting scholar at Leiden University.

María Luna (PhD Communication Contents at the Digital Age, Universitat Autònoma de Barcelona, UAB) teaches as an Adjunct Lecturer at Tecnocampus ESUPT - UPF (Universitat Pompeu Fabra, Barcelona). As a member of the research groups Narrativas de la Resistencia (UPF) and Grup Internacional d'Estudis sobre Comunicació y Cultura (UAB), she has published several essays on documentary, transnational cinema, audiovisual distribution and public television. She has co-edited the volume Culturas indigenas, investigación, comunicación y resistencia (2018) along with Amparo Huertas-Bailén, and is currently working on a volume on new approaches to documentary research and practice with Pablo Mora and Daniela Samper. Moreover, she is an academic co-coordinator and curator at MIDBO (International 


\section{List of Contributors}

Documentary Film Festival in Bogotá) and a member of ECREA, NECS and HoMer Network.

Maurizia Natali (PhD Film Aesthetics, Sorbonne Nouvelle, France) has taught Film and Art History at RISD (1996-2016), RI College and Brown University. She has lectured in New York, Providence, Montreal, Cerisy, London, Rome and Lisbon. She published the book L'Image-Paysage, Iconologie et Cinéma (1996) and numerous essays, such as "The Sublime Excess of the American Landscape. Dances with Wolves and Sunchaser as Healing Landscapes" (2001), "Warburg et Godard. La mise en scene de l'ecran" (2004), “The Course of Empire: Sublime Landscapes in American Cinema" (2006), "L'installazione post-cinematica in Aurelien Froment" (2012), "Il corpo delle donne by Lorella Zanardo. Allegoria della pornocrazia italiana” (2013), "Gradivae \& Nymphs: Walking Women in Italian Cinema” (2015) and "Avatar, SF mannerism in the Anthropocene" (Forthcoming), among others. Recently, she lectured at the French Studies Conference 'Sous le Pave' conference (Providence, RI) with a lecture titled, “Agnès Varda: Voyages aux marges de l'Anthropocène, ou Le peuplen'a pas (encore) disparu”.

María Novela de Aragón (M.Sc. Architecture, Superior Technical School of Architecture of Madrid, Spain) is one of the co-founders of Cabana Partners for Architecture, an architectural firm based in Madrid, where she currently works. As a researcher, she has focused on the use of staircases in film, especially on the morphological features that make them so useful to filmmakers.

Anna Poupou (PhD Film Studies, Sorbonne Nouvelle, France) teaches as an Adjunct Lecturer at the Theatre Studies Department, National \& Kapodistrian University of Athens and at the Hellenic Open University. She has worked as a programmer at the Greek Film Archive and collaborated as a researcher with the Department of Communication and Media of the University of Athens for the European programme I-Media Cities. Her research interests focus on the history of Greek cinema, the urban space in film and the Greek film noir, subjects on which she has co-edited three collective volumes - City and Cinema: Theoretical and Methodological Approaches (2011), Athens: World Film Locations (2014), The Lost Highway of Greek Cinema 19601990 (2018) - and a thematic issue at the Filmicon. Journal of Greek Film Studies.

Filipa Rosário (PhD Artistic Studies - Audiovisual and Cinema Studies, University of Lisbon, Portugal) is a Postdoctoral Researcher in the Centre for Comparative Studies at the University of Lisbon, where she is developing a research project on landscape and Portuguese cinema. She coordinates the project 'Cinema and the World - Studies on Space and Cinema' at the same centre and also co-coordinates 
the 'Landscape and Cinema' work group at AIM - Association of the Moving Image Researchers, whose Directive Board she currently integrates. She is the author of the book O Trabalbo do Actor no Cinema de John Cassavetes (The Actor's Craft in the Cinema of John Cassavetes, 2017).

Paolo Simoni (PhD Cultural Heritage, Turin Polytechnic, Italy) is a Founding Member and current Director of the Italian Amateur Film Archive (Home Movies - Archivio Nazionale del Film di Famiglia, Bologna, www.homemovies.it). His interests are in both academic research and audiovisual production. As a research fellow at the University of Padua (2016-2017) and formerly at the University of Modena and Reggio Emilia, he is engaged in projects on recovering and studying archival film materials. He has written several essays on amateur cinema, focusing primarily on the relation between audiovisual sources, personal stories and history, as well as the book Lost Landscapes. Il cinema amatoriale e la città (2018). As an author, curator and producer, he has completed a large number of audiovisual archive-based projects, including found footage films (Catherine, Formato Ridotto, Miss Cinema - Archivio Mossina), installations (Expanded Archive), exhibitions (Family, Cinematic Bologna) and apps (Play the City).

Bruno Surace is a PhD student in Semiotics and Media at the University of Turin and a Member of AISS (Associazione Italiana Studi Semiotici), CUC (Consulta Universitaria Cinema) and CIRCe (Centro Interdipartimentale di Ricercasulla Comunicazione, Turin). He is currently editing two books, one on the representations of catastrophe and the other about the Japanese imaginary in Western society. He has published several articles in peer-reviewed journals, participated in European summer schools and given lectures in international conferences and seminars. Moreover, in the first semester of 2017, he was a visiting scholar in the Department of Film and Screen Media at UCC (University College Cork, Ireland). Finally, as a film critic, he participates in a weekly Italian radio show.

Iván Villarmea Álvarez (PhD History of Art, Universidad de Zaragoza, Spain) works as a Postdoctoral Researcher at Universidade de Santiago de Compostela (Galicia, Spain). His research career is focused on the representation of space and landscape in films, a subject on which he published the book Documenting Cityscapes. Urban Change in Contemporary Non-Fiction Film (2015) and a special issue -edited with Filipa Rosário - in Aniki. Portuguese Journal of the Moving Image (2017). Moreover, since 2011, he has contributed to the online film journal A Cuarta Parede, for which he has co-edited the volume Jugar con la Memoria. El Cine Portugués en el Siglo XXI (2014) along with Horacio Muñoz Fernández. 
